\title{
POTENSI ATMOSFER DALAM PEMBENTUKAN AWAN KONVEKTIF PADA PELAKSANAAN TEKNOLOGI MODIFIKASI CUACA DI DAS KOTOPANJANG DAN DAS SINGKARAK 2010
}

\author{
Djazim Syaifullah ${ }^{1}$
}

\begin{abstract}
Study the potential of the atmosphere on the formation and growth of convective clouds during the implementation of Weather Modification Technology (TMC) has been done with observational data came from Padang, West Sumatra station. A further 330 pieces of observation data at $\mathrm{OOZ}$ and $12 Z$ each day from June to November 2010 has been analyzed. By the RAOB application analysis conducted to determine the parameters and indices as sounding estimators of potential atmospheric in the region. Moisture content analysis results that represented by the value of Mixing Ratio (MR) and Precipitable Water (PW) showed that during the months of water vapor content is quite large, the rainfall was influenced by atmospheric unstability could indicated by several indexes. If unstability on the day was good enough, then the precipitation will be even greater.
\end{abstract}

\section{Intisari}

Kajian potensi atmosferterhadap proses pembentukan dan pertumbuhan awan konvektif pada saat pelaksanaan Teknologi Modifikasi Cuaca (TMC) telah dilakukan dengan data pengamatan sounding dari stasiun Tabing Sumatera Barat. Sebanyak 330 buah data pengamatan harian jam $00 Z$ dan $12 Z$ dari Juni sampai dengan Nopember 2010 telah dianalisis. Dengan aplikasi RAOB analisis dilakukan untuk menentukan parameter dan indeks radiosonde sebagai penduga potensi atmosfer di wilayah tersebut. Hasil analisis kandungan uap air yang diwakili oleh nilai Mixing Ratio dan PW menunjukkan bahwa selama bulan-bulan tersebut kandungan uap air cukup besar, presipitasi yang dihasilkan dipengaruhi oleh labilitas atmosfer yang diindikasikan oleh beberapa indeks radiosonde. Apabila labilitas pada hari itu cukup baik, maka peluang presipitasinya akan semakin besar.

Kata kunci : Awan konvektif, indeks radiosonde

\section{PENDAHULUAN}

Hujan adalah parameter iklim yang cukup penting, hujan adalah status terakhir dari proses pertumbuhan awan. Untuk lebih memahami proses fisis dan mekanisme terbentuknya awan, profil udara atas sangat penting untuk dipelajari karena sebagai media terbentuknya awan. Beberapa prakondisi udara atas merupakan media pertumbuhan awan yang baik adalah : labilitas suhu, kelembaban, dan angin yang mendukung untuk pertumbuhan awan.

Hujan yang merupakan proses akhir dari dinamika awan sangat bermanfaat sebagai sumber daya air di atmosfer yang jatuh ke permukaan. Pemanfaatan sumber daya air ini misalnya dalam bentuk sumber energi listrik dalam Pembangkit Listrik Tenaga Air (PLTA) yang memanfaatkan

\footnotetext{
${ }^{1}$ Peneliti Madya - UPT Hujan Buatan, BPPT, Thamrin No. 8

Jakarta, email djazim@yahoo.com
}

aliran masuk (inflow) dalam suatu Daerah Aliran Sungai (DAS).

Penerapan Teknologi Modifikasi Cuaca (TMC) telah dilakukan di DAS Kotapanjang dan DAS Singkarak pada selang antara bulan Juni dan Nopember 2010, dengan tujuan untuk menambah inflow yang masuk ke PLTA Waduk Kotapanjang dan PLTA Danau Singkarak. Pelaksanaan kegiatan TMC dilakukan dalam tiga tahap : tahap pertama tanggal 22 Juni sampai dengan 11 Juli 2010, tahap kedua tanggal 12 sampai dengan tanggal 21 Juli 2010 dan tahap ketiga tanggal 8 sampai dengan 27 Nopember 2010. Selama pelaksanaan TMC tersebut kondisi cuaca di amati secara seksama dari berbagai sumber data diantaranya, pengamatan suhu permukaan di Pos Meteorologi (Posmet) yang berfungsi juga sebagai pos pengamatan pertumbuhan awan, pengamatan citra satelit di wilayah target, pengamatan dengan radar bergerak (mobile radar), pengamatan sinoptik 
yang meliputi angin gradien dan suhu muka laut, serta pengamatan kondisi udara atas (profil suhu) dengan data radiosonde.

Dari profil suhu dapat diketahui dinamika serta kelembaban udara (atmosfer) yang dapat mendukung proses pembentukan dan pertumbuhan awan khususnya awan konvektif berdasarkan data pengukuran radiosonde yaitu profil tekanan udara, suhu lingkungan, suhu titik embun (kelembaban), arah dan kecepatan angin.

Studi ini akan mempelajari hubungan variabilitas suhu, kelembaban dan angin terhadap proses pertumbuhan awan. Materi yang dibahas dibatasi pada awan konvektif, yaitu awan yang terbentuk akibat proses konveksi dari pemanasan surya. Peluang pertumbuhan didekati dengan data curah hujan dengan asumsi hujan yang terjadi akibat awan konvektif.

Data yang dipakai adalah data pengukuran "udara atas" (upper air observation) yang berupa hasil pengamatan profil suhu, suhu titik embun, arah dan kecepatan angin.

Sebelum memahami variabilitas parameter cuaca dihubungkan dengan peluang pertumbuhan awan konvektif, terlebih dulu diuraikan proses pertumbuhan awan dan bagaimana media yang baik untuk pertumbuhan awan.

\section{TINJAUAN TEORI PERTUMBUHAN AWAN}

Yang dimaksud dengan proses pertumbuhan awan di sini adalah proses pertumbuhan awan konvektif. Awan konvektif adalah awan yang dihasilkan oleh proses konveksi akibat pemanasan radiasi surya. Energi radiasi surya yang memanasi permukaan tanah menyebabkan suhu lingkungan permukaan naik sehingga mencapai suhu konveksi, akibatnya suhu massa udara lebih tinggi dari suhu lingkungannya sehingga massa udara mampu naik ke level yang lebih tinggi.

Awan konvektif (awan tipe cumulus) dalam pertumbuhannya sampai turun sebagai hujan mempunyai tiga tahapan, yaitu tahap pertumbuhan (growth stage), tahap matang (mature stage) dan tahap disipasi (dissipation stage) atau jatuh sebagai hujan (Rogers, 1979; Salby, 1996)

\subsection{Tahap pertumbuhan}

Uap air yang terkandung dalam parsel massa udara yang naik ke level yang lebih tinggi akan berkondensasi pada inti kondensasi yang tersedia apabila suhu lingkungan di level tersebut sama dengan suhu titik embun parsel udara. Level dimana parsel udara mulai berkondensasi dikenal sebagai dasar awan. Dalam perubahan fasa (fasa uap menjadi fasa cair) akan dikeluarkan panas laten yang dikonversikan menjadi tenaga kinetik pergerakan parsel udara serta butir-butir air ke level yang lebih tinggi lagi (Irribane and Godson, 1981). Selama uap air dapat berkondensasi, panas laten akan selalu bertambah dan parsel udara serta butir air akan terus naik ke level yang lebih tinggi sampai ditemui kondisi udara yang stabil. Level dimana parsel massa udara serta butir air tidak dapat naik lagi disebut puncak awan.

Selama proses pertumbuhan, pergerakan secara vertikal didominasi pergerakan ke atas. Bila butir air dalam awan yang terbentuk cukup kecil (kurang 18 mikron) butir air dalam awan akan membesar dengan cara memanfaatkan uap air yang tersedia (Rogers, 1979), sehingga proses pembesaran butir air / awan akan memakan waktu yang lama sampai mencapai ukuran butir hujan. Untuk memperbesar ukuran butir air atau droplet menjadi butir hujan yang siap jatuh diperlukan pembesaran sekitar 104 kali.

Sebaliknya bila ada butir air / awan yang ukurannya relatif lebih besar (lebih besar atau sama dengan 20 mikron) maka proses secara berantai tumbukan dan penggabungan antar butirbutir air akan dimulai yang mana membantu proses pembesaran butir air lebih cepat.

\subsection{Tahap pematangan}

Butir-butir air dalam awan akan terus membesar melalui proses tumbukan dan penggabungan (collision dan coalesence) (Rogers, 1979; Salby, 1996) sampai mencapai ukuran butir maksimum dalam kondisi lingkungan yang dimilikinya. Dalam tahap ini masih terus berlangsung kondensasi dan pembesaran butir secara simultan, sehingga gerakan vertikal di dalam awan ada yang masih ke atas (up draft) dan ada yang mulai ke bawah (down draft). Di dalam proses tumbukan dan penggabungan mempunyai efisiensi tertentu yang merupakan fungsi dari jarijari butir air (droplet).

Proses pertambahan ukuran butiran (pembesaran) dipengaruhi oleh konsentrasi butiran air di dalam awan (yang dinyatakan dalam liquid water content - LWC), efisiensi pengumpulan, kecepatan jatuh butir, up draft dan lintasannya. Persamaan matematisnya dapat dinyatakan sebagai : (Wallace and Hobbs, 1977).

$$
\frac{d R}{d z}=\frac{\bar{E} M}{4 \mathrm{r}_{L}} \frac{u}{w-}
$$

Butir-butir air yang sudah besar akan turun ke level yang lebih rendah dan berkumpul pada dasar awan sampai mencapai ukuran sedemikian rupa sehingga gaya berat akan mendominasi gaya-gaya yang bekerja pada butiran air tersebut. Bila kondisi ini tercapai maka hujan mulai turun dan awan disebut dalam tahap disipasi atau mati.

\subsection{Tahap disipasi}

Dalam tahap ini, gerakan vertikal didominasi oleh gerakan ke bawah. Butir-butir air yang ukurannya cukup besar akan turun sebagai hujan, 
sementara butir-butir air yang masih kecil akan menguap kembali. Dalam awan cumulus tahap ini berlangsung relatif cepat dengan intensitas hujan relatif tinggi.

Proses kondensasi sulit terjadi pada udara yang bersih (tanpa inti kondensasi), inti kondensasi dapat berupa aerosol ataupun partikel-partikel debu di udara.

\section{DATA DAN METODE}

Dengan mempelajari proses pembentukan dan pertumbuhan awan, terlihat bahwa diperlukan kondisi atmosfer yang mendukung untuk terjadinya pembentukan dan pertumbuhan awan. Pengamatan profilsuhu lingkungan, suhu titikembun, kelembaban dan kecepatan angin digunakan untuk menganalisa media pertumbuhan awan apakah mendukung atau tidak untuk pembentukan dan pertumbuhan awan. Pembentukan dan pertumbuhan awan memerlukan atmosfer yang tidak stabil, kandungan uap air yang cukup, radiasi surya yang baik dan angin yang mendukung. Dengan mempelajari parameter tersebut dapat dianalisa peluang pertumbuhan awan.

Pengamatan parameter-parameter ini dilakukan dengan meluncurkan balon rawinsonde suatu alat telemetri yang mengukur kondisi udara atas meliputi pengukuran suhu lingkungan, tekanan udara, kelembaban relatif dan angin.

Hasil analisa ini dibandingkan dengan data curah hujan yang merepresentasikan pertumbuhan awan dengan asumsi hujan yang dihasilkan adalah hujan konvektif dari awan cumulus.

Curah hujan didapat dari beberapa stasiun penakar curah hujan. Dengan beberapa pertimbangan pengambilan curah hujan wilayah dilakukan dengan pererataan aljabar.

Ada beberapa parameter data rawinsonde yang digunakan untuk analisis dan prediksi pertumbuhan awan konvektif. Pada dasarnya parameter tersebut mengarah pada : parameter moisture (kandungan massa uap air yang ada di atmosfer), parameter kelabilan (sebagai sarana atau media untuk terjadinya konvektivitas di atmosfer) dan parameter kelembaban (sebagai pendukung dari moisture yang ada untuk terjadi pembentukan awan) serta parameter angin (sebagai supplay massa uap air dari luar atau sebagai mass transport). Dari parameter tersebut muncul beberapa Indeks untuk menggambarkan / menduga kondisi udara pada saat terukur.Sebelum menujuk ke analisis indeks rawinsonde perlu dianalisis parameter rawinsonde yang lain sebagai pembanding dalam studi kasus ini.

Parameter tersebut adalah parameter moisture yang disebut Mixing Ratio (MR) dan Precipitable water (PW).

Mixing Ratio : adalah perbandingan massa uap air mv dengan massa udara kering md yang terdapat dalam satu volume tertentu, dapat diekspresikan dalam bentuk :(Roger, 1979).

$$
M R \equiv \frac{m_{v}}{m_{d}}
$$

Mixing ratio umumnya dinyatakan dalam $\mathrm{g} / \mathrm{kg}$ udara kering. Di atmosfer lintang tengah besarnya MR umumnya beberapa $\mathrm{g} / \mathrm{kg}$, sementara di daerah tropis mencapai 10 sampai $16 \mathrm{~g} / \mathrm{kg}$, pada kondisi udara basah bahkan mencapai $20 \mathrm{~g} / \mathrm{kg}$. Dengan mengetahui mixing ratio pada suatu daerah tertentu kita dapat melihat kebasahan udara / kandungan massa uap air, sehingga potensi untuk terbentuknya awan konvektif dapat diprakirakan.

Pada pengukuran rawinsonde perhitungan MR dilakukan dengan pendekatan empiris sebagai fungsi dari profil tekanan (dalam milibar) dan profil suhu (dalam ${ }^{\circ} \mathrm{C}$ ) karena yang terukur adalah data tekanan dan suhu (bukan mengukur kandungan uap air). Persamaan empiris tersebut adalah (Glickman, 2000) :

$$
M R=\frac{0.622 \cdot p}{p-e}
$$

dengan :

$\mathrm{p} \quad$ : tekanan udara lingkungan (dalam milibar)

e : tekanan uap air jenuh (vapor pressure)

Precipitable water (PW) : didefinisikan sebagai ekivalen dari jumlah air di kolom udara (yang diekspresikan oleh nilai MR) apabila semua uap air pada kolom udara tersebut mengembun. Proses pengembunan tersebut dipengaruhi oleh perbandingan densitas air dan densitas udara $\left(\rho_{w} / \rho_{a}\right)$ juga oleh tekanan masing-masing kolom udara tersebut. Perhitungan PW dilakukan dengan mengintegrasikan uap air yang ada pada kolom udara dari permukaan (surface) sampai level ketinggian tertentu (biasanya sampai 500 mbar $=18000$ kaki). PW secara empiris dihitung dengan persamaan : (Glickman, 2000).

$$
P W=0.0004 \int_{p 0}^{p z} q \cdot d p
$$

dimana :

PW : Precipitable Water (dalam inch)

q : perbandingan densitas air dengan densitas udara $\left(\rho_{\mathrm{w}} / \rho_{\mathrm{a}}\right)$.

Nilai PW menggambarkan potensi uap air yang dapat menjadi awan-awan potensial.

\subsection{Indeks-indeks sounding}

Ada beberapa macam indeks dalam analisa udara atas yang berguna untuk melihat kelabilan udara, peluang pertumbuhan awan konvektif, peluang terbentuknya badai (thunderstorm) dan lain-lain. Pada kenyataannya indeks-indeks tersebut menganalisa data di lapisan mandatory (lapisan pada paran $850 \mathrm{mb}, 700 \mathrm{mb}, 500 \mathrm{mb}$ dan 
200mb). Beberapa indeks yang cukup penting diantaranya adalah :

\subsubsection{Showalter Indeks (SI)}

Indeks ini digunakan secara umum untuk menentukan tingkat stabilitas atmosfer. Indeks stabilitas inijuga biasa digunakan untuk menentukan potensi thunderstorm. Nilai SI dihitung dengan mengangkat parsel udara dari level $850 \mathrm{mb}$ ke level $500 \mathrm{mb}$ secara adiabatik. Selisih antara suhu parsel udara dengan suhu lingkungan di level 500 $\mathrm{mb}$ disebut SI.

\subsubsection{Lifted Indeks (LI)}

Nilai LI dihitung dengan mengangkat parsel udara dari level dekat permukaan ( setebal $50 \mathrm{mb}$ dari permukaan / sekitar 30 feet) sampai dengan level $500 \mathrm{mb}$ secara adiabatik. Selisih suhu parsel tersebut dengan suhu lingkungannya pada level $500 \mathrm{mb}$ disebut dengan $\mathrm{LI}$.

Lifted indeks merupakan modifikasi dari Showalter indeks yang biasanya banyak dipakai untuk melihat kelabilan dalam kondisi konvektif frontal (frontal convective weather).

Masing-masing nilai SI maupun LI mempunyai nilai batas ambang untuk menduga potensi thunderstorm. Nilai batas ambang kedua parameter tersebut dapat dilihat pada Tabel 1.

\subsubsection{K Indeks}

$\mathrm{K}$ Indeks merupakan penduga stabilitas suhu dan kelembaban :

$$
K_{\text {indeks }}=T_{850}-T_{700}-T_{500}+T d_{850}+T d_{700}
$$

$\mathrm{T}_{850}$ : suhu lingkungan $\left({ }^{\circ} \mathrm{C}\right)$ pada paras $850 \mathrm{mbar}$ $\mathrm{T}_{700}^{850}$ : suhu lingkungan $\left({ }^{\circ} \mathrm{C}\right)$ pada paras $700 \mathrm{mbar}$ $\mathrm{T}_{500}^{700}$ : suhu lingkungan $\left({ }^{\circ} \mathrm{C}\right)$ pada paras $500 \mathrm{mbar}$ $\mathrm{Td}_{850}^{500}$ : suhu dew point $\left({ }^{\circ} \mathrm{C}\right)$ pada paras $850 \mathrm{mbar}$ $\mathrm{Td}_{700}$ : suhu dew point $\left({ }^{\circ} \mathrm{C}\right)$ pada paras $700 \mathrm{mbar}$

\subsubsection{Total-total Indeks}

Nilai indeks ini umumnya dipakai untuk indikator cuaca buruk dan didasarkan pada data suhu dan moisture (kelembahan) di mandatory level. Total-total merupakan kombinasi dari Cross Total $(C T) \sim$ gabungan dari pengukuran moisture dan lapse rate, dengan Vertical Total (VT) yang mengindikasikan lapse rate antara level $850 \mathrm{mb}$ dengan $500 \mathrm{mb}$.

$$
\text { TTindek }=T_{850}+T d_{850}-2 \cdot T_{500}
$$

dimana :

$\begin{array}{ll}\mathrm{T}_{850} & \text { : suhu lingkungan pada } 850 \mathrm{mbar} \\ \mathrm{T}_{550} & \text { : suhu lingkungan pada } 500 \mathrm{mbar} \\ \mathrm{Td}_{850} & \text { : suhu titik embun pada } 850 \mathrm{mbar}\end{array}$

\subsubsection{Sweat Indeks}

Sweat indek dibuat untuk membantu memprediksi kemungkinan-kemungkinan cuaca yang terjadi. Kemungkinan-kemungkinan yang dimaksud adalah kemungkinan terbentuknya awan cumulus atau badai guntur yang menggambarkan cuaca buruk dan aktifitas tornado (Djuric, 1994).

$$
S W E A T=12 \cdot T d_{850}+20 \cdot(T T-49)+2 \cdot F_{850}+F_{500}
$$

dimana :

TT : nilai Total-totals Indeks

$\mathrm{F}_{850} \quad$ : kecepatan angin di level $850 \mathrm{mbar}$

$\mathrm{F}_{500}^{850} \quad$ : kecepatan angin di level 500 mbar

Nilai KI, TTI dan SWEAT Indeks mempunyai batas ambang untuk menentukan kondisi atmosfer seperti terlihat pada tabel berikut.

Tabel 1. Nilai ambang untuk penduga potensi Thunderstorm beberapa indek radiosonde

\begin{tabular}{|c|c|c|c|}
\hline \multirow{2}{*}{ Indeks } & \multicolumn{3}{|c|}{ Potential Thunderstorm } \\
\cline { 2 - 4 } & Weak & Moderate & Strong \\
\hline Lifted & $>-3$ & $-3 \sim-5$ & $<-5$ \\
\hline Showalter & $>4$ & $4 \sim-4$ & $<-4$ \\
\hline $\mathrm{K}$ & $<25$ & $25 \sim 35$ & $>35$ \\
\hline TT indek & $<45$ & $45 \sim 55$ & $>55$ \\
\hline SWEAT & $<300$ & $300 \sim 600$ & $>600$ \\
\hline \\
sumber: The Universal RAwinsonde \\
OBservation program (RAOB)
\end{tabular}

\subsection{Data}

Data yang dipakai adalah data pengukuran sounding radiosonde stasiun Tabing, Padang Sumatera Barat mulai bulan Juni sampai dengan bulan Nopember 2010. Data peluncuran radiosonde secara lengkap dapat diunduh di situs : http:// weather.uwyo.edu/upperair/sounding.html. Format data dalam bentuk ASCII yang dapat langsung dilihat isi filenya sehingga dapat diproses dengan mudah. Sepanjang bulan bulan pengamatan tersebut telah diluncurkan pengamatan sounding 330 buah, dengan pengamatan pada jam 07.00LT (O0UTC) sebanyak 167 dan jam 19.00LT (12UTC) sebanyak 163. Tabel 2. menunjukkan data tiap bulannya :

Tabel 2. Jumlah pengamatan radiosonde stasiun Tabing bulan Juni - Nopember 2010

\begin{tabular}{|c|c|c|c|c|c|c|c|}
\hline & Jun & Jul & Ags & Sep & Okt & Nop & Tot \\
\hline $00 Z$ & 28 & 31 & 29 & 21 & 29 & 29 & 167 \\
\hline $12 Z$ & 26 & 29 & 29 & 21 & 28 & 30 & 163 \\
\hline Jml & 54 & 60 & 58 & 42 & 57 & 59 & 330 \\
\hline
\end{tabular}


Data curah hujan yang dipakai adalah data pengukuran curah hujan pada tanggal 21 Juni 2010 sampai dengan 26 Nopember 2010 pada saat pelaksanaan Teknologi Modifikasi Cuaca (TMC) DAS Kotapanjang dan DAS Singkarak. Sebanyak 23 data stasiun dipakai dalam analisis ini, 14 buah terletak di wilayah DAS Kotobanjang dan 9 buah terletak di wilayah DAS Singkarak. Tabel berikut memuat nama-nama stasiun untuk kedua DAS.

Tabel 3. Stasiun pengamatan curah hujan DAS Kotapanjang dan DAS Singkarak yang didapat pada kegiatan Teknologi Modifikasi Cuaca 2010

\begin{tabular}{|l|l|l|l|}
\hline \multicolumn{2}{|l|}{ DAS Kotopanjang } & \multicolumn{2}{l|}{ DAS Singkarak } \\
\hline No & Stasiun & No & Stasiun \\
\hline 1 & Koto Bangun & 1 & Ombilin Weir \\
\hline 2 & Muaro Paiti & 2 & Sumpur Kudus \\
\hline 3 & Kuto Tuo & 3 & Intake Malalo \\
\hline 4 & Gn. Malintang & 4 & Junjung Sirih \\
\hline 5 & Pangkalan & 5 & Gubang Gajah \\
\hline 6 & Lubuk Jantan & 6 & Panarian \\
\hline 7 & Tanjung & 7 & Lubuk Sulasih \\
\hline 8 & Gn. Malalo & 8 & Danau Kembar \\
\hline 9 & Dusun Tigo & 9 & Sumani \\
\hline 10 & Bandur Picak & 10 & Batipuh \\
\hline 11 & Batu Basurat & 11 & Posmet malalo \\
\hline 12 & PLTA Kt. Pnjang & & \\
\hline 13 & Rimbo Data & & \\
\hline 14 & Lubuk Sikaping & & \\
\hline
\end{tabular}

Sumber : UPT Hujan Buatan BPPT

\section{HASIL DAN PEMBAHASAN}

Analisis data souunding dilakukan dengan menghitung nilai-nilai indeks terhadap semua data pengamatan. Perhitungan parameter dilakukan dengan perangkat lunak (software) RAOB versi 6.1 (RAwindsonde OBservation program). Software RAOB merupakan aplikasi analisis sounding yang mampu membaca data sounding dari 35 format yang berbeda. Software in juga mampu menampilkan plot interaktif dalam bentuk T-Skew / Log P, emagram, tephigram, hodograph serta cross-section, mampu menghitung puluhan parameter atmosfer, storm analysis serta masih banyak fitur-fitur lainnya, sehingga Aplikasi RAOB untuk melakukan analisis data radiosonde sangat bermanfaat karena mempunyai fitur parameter atmosfer yang lengkap dan dapat dilakukan dengan cepat

Dari hasil analisis selama bulan pengamatan secara umum menunjukkan nilai parameter ataupun indeks yang bervariasi. Nilai rerata dari mixing ratio sebesar $18 \mathrm{~g} / \mathrm{kg}$, precipitable water (PW) sebesar $60 \mathrm{~mm}$, SI sebesar 0.1, LI sebesar -2.8, KI sebesar 35, Total-totals sebesar 44 dan SWEAT sebesar 215. Secara umum dari kondisi parameter dan indeks tersebut dan mengacu pada Tabel 1 dapat dilihat bahwa potensi atmosfer dalam kategori lemah (weak) sampai sedang (moderate). Rerata curah hujan wilayah (untuk kedua DAS Kotapanjang dan Singkarak) yang dihasilkan per hari sekitar $7.5 \mathrm{~mm} /$ hari. Berikut pada Gambar 1 adalah contoh analisis yang dihasilkan oleh RAOB untuk tanggal 29 Juni 2010.

Analisis parameter maupun indeks radiosonde adalah sebagai berikut :

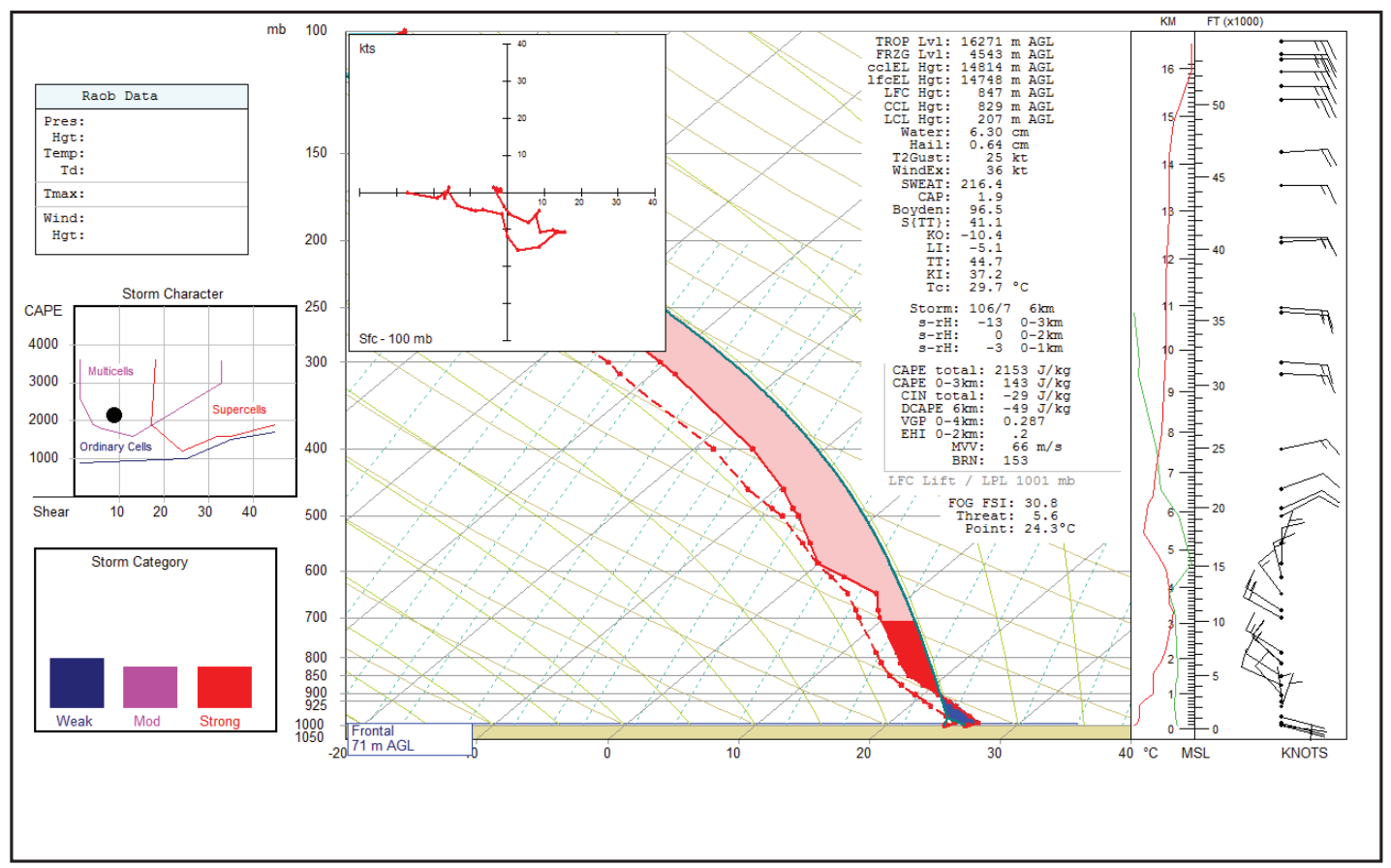

Gambar 1. Profil sounding pada tanggal 29 Juni 2010 jam 00UTC dengan program RAOB 


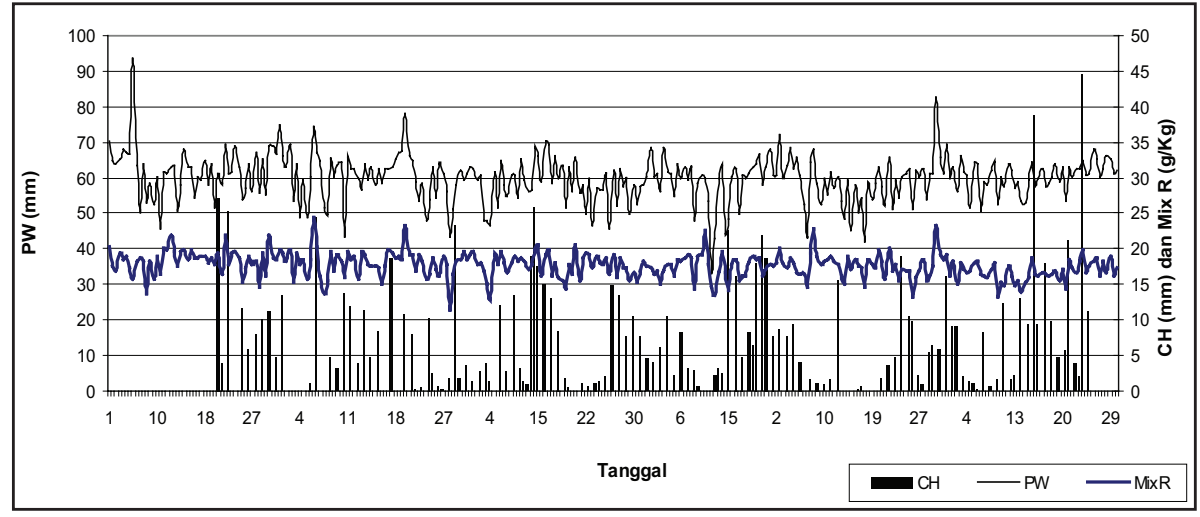

Gambar 2. Profil Precipitable Water dan Mixing Ratio dibandingkan dengan curah hujan rerata DAS Kotapanjang dan DAS Singkarak, garis tipis adalah PW, garis tebal adalah Mixing Ratio dan bar adalah curah hujan)

\subsection{Mixing Ratio}

Nilai rerata Mixing Ratio selama bulan tersebut sekitar $18 \mathrm{~g} / \mathrm{Kg}$ dengan nilai minimum sebesar $11 \mathrm{~g} / \mathrm{Kg}$ dan nilai maksimum sebesar 24.g/ Kg.. Dari gambar 2 di bawah ini terlihat bahwa secara umum fluktuasinya tidak mengikuti pola curah hujan maupun PW, sehingga dapat dikatakan bahwa mixing ratio adalah jumlah kandungan air di atmosfer yang tidak semuanya menjadi presipitasi, hal ini dipengaruhi oleh tingkat labilitas atmosfer pada saat itu.

\subsection{Precipitable Water (PW)}

Nilai rerata Precipitable Water selama bulan tersebut sekitar $60 \mathrm{~mm}$ dengan nilai minimum 42 mm dan maksimum 93 mm. Dari Gambar 2 terlihat bahwa pada hari-hari dimana banyak kejadian hujan nilai PW cenderung naik, tetapi kenaikan nilai PW tidak selalu diikuti dengan kejadian hujan yang cukup signifikan. Hal ini mengindikasikan bahwa apabila kandungan uap air di atmosfer besar (nilai PW tinggi) apabila potensi atmosfernya mendukung akan menghasilkan presipitasi, tetapi apabila kurang mendukung maka tidak terjadi presipitasi yang signifikan.

\subsection{Lifted Indeks}

Profil nilai Lifted Indeks selama bulan Juni sampai dengan bulan Nopember 2010 disajikan dalam Gambar 3. Nilai rerata selama bulan tersebut sebesar -2.8 termasuk dalam kategori lemah (weak).

\subsection{Showalter Indeks}

Profil nilai Showalter Indeks selama bulan Juni sampai dengan bulan Nopember 2010 disajikan dalam Gambar 3. Nilai rerata selama bulan tersebut sebesar +0.1 termasuk dalam kategori sedang (moderate).

Dari kedua nilai tersebut menunjukkan bahwa kondisi atmosfer selama pengamatan secara umum masuk dalam kategori tidak stabil (unstable).

Dari hasil analisis lebih lanjut terlihat bahwa pada umumnya presipitasi (kejadian hujan) terjadi pada kondisi kedua indeks (LI dan SI) bernilai negatif, meskipun tidak untuk semua kejadian hujan.

\section{5. $\mathrm{K}$ Indeks}

Profil nilai K Indeks selama bulan Juni sampai

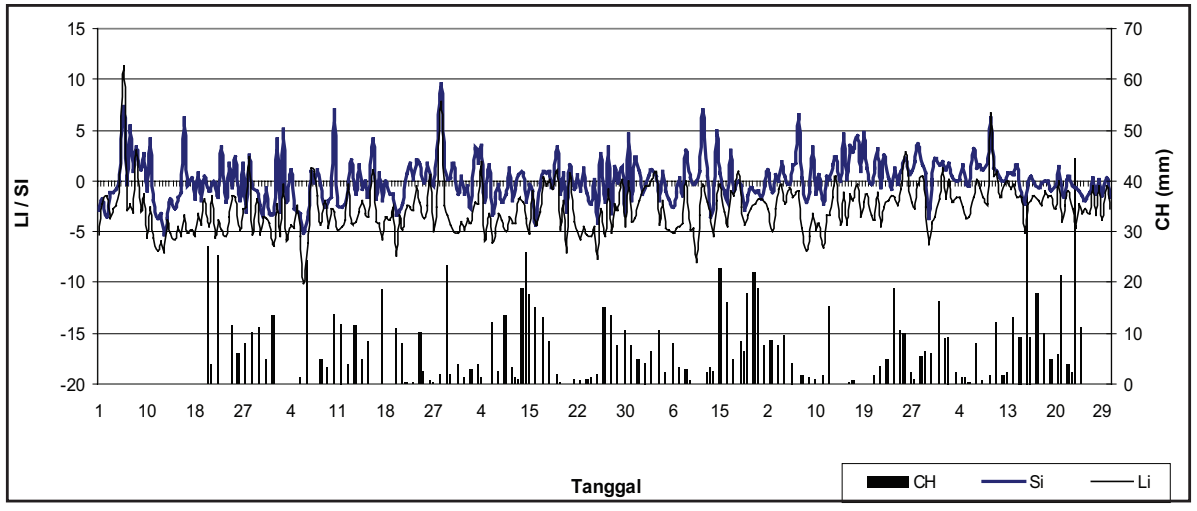

Gambar 3. Profil Showalter Indeks (SI) dan Lifted Indeks (LI) dibandingkan dengan curah hujan rerata DAS Kotapanjang dan DAS Singkarak, garis tipis adalah LI, garis tebal adalah SI, bar adalah curah hujan) 
dengan bulan Nopember 2010 disajikan dalam Gambar 4. Nilai rerata selama bulan tersebut sebesar 35 termasuk dalam kategori sedang (moderate). Dari nilai ini terlihat secara umum kandungan moisture dan tingkat labilitas cukup mendukung untuk pertumbuhan awan konvektif.

\subsection{Total-totals Indeks}

Profil nilai Total-totals Indeks selama bulan Juni beberapa indeks radiosonde tersebut. Apabila labilitas pada hari itu cukup baik, maka peluang presipitasinya akan semakin besar. Secara umum kondisi atmosfer selama bulan Juni sampai dengan bulan Nopember 2010 cukup mendukung untuk pertumbuhan awan. Dari pemantauan curah hujan terlihat bahwa selama kegiatan TMC telah terjadi hujan di kedua DAS dengan intensitas ringan sampai besar.

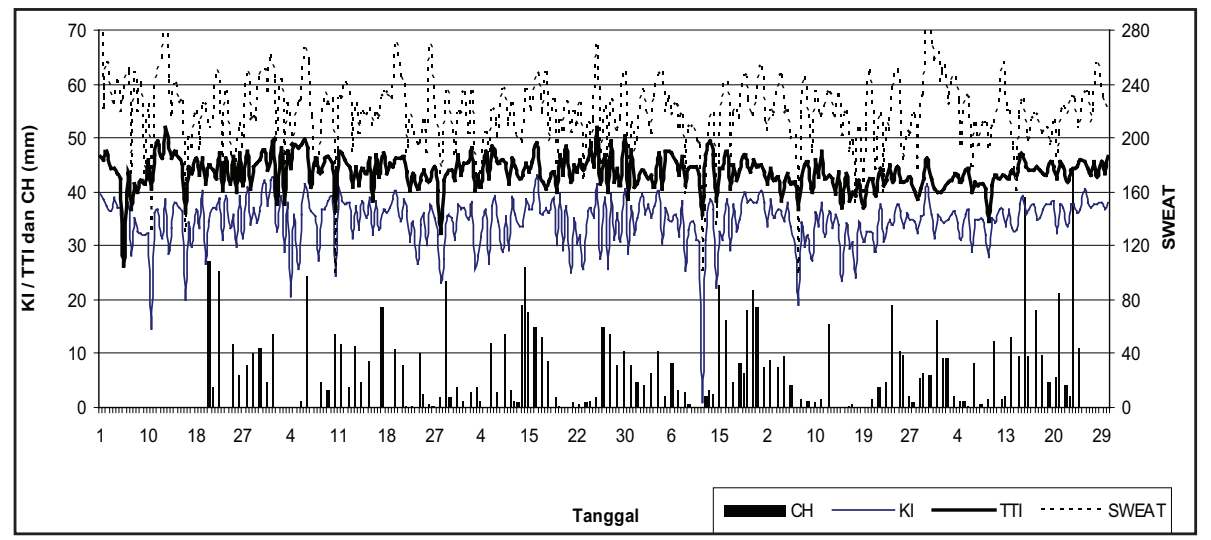

Gambar 4. Profil K indeks (KI), Total-total Indeks (TTI) dan SWEAT Indeks dibandingkan dengan curah hujan rerata DAS Kotapanjang dan DAS Singkarak, garis tipis : KI, garis tebal (tengah) : TTI, garis putus-putus (atas) : SWEAT dan bar : curah hujan)

sampai dengan bulan Nopember 2010 juga disajikan dalam Gambar 4. Nilai rerata selama bulan tersebut sebesar 44 termasuk dalam kategori lemah (weak) dan sedikit dibawah kategori moderate.

\subsection{Sweat Indeks}

Profil nilai Sweat Indeks selama bulan Juni sampai dengan bulan Nopember 2010 disajikan dalam Gambar 4. Nilai rerata selama bulan tersebut sebesar 215 dan maksimum sebesar 324, termasuk dalam kategori lemah (weak). Dari nilai dan kategori tersebut juga menunjukkan bahwa selama pengamatan tidak banyak terjadi thunderstorm yang diakibatkan oleh kondisi supersel / cumulonimbus. Selama pengamatan tercatat hanya 5 kejadian yang mempunyai nilai Sweat kategori moderate.

\section{KESIMPULAN}

Aplikasi RAOB untuk melakukan analisis data radiosonde sangat bermanfaat karena mempunyai fitur parameter atmosfer yang lengkap dan dapat dilakukan dengan cepat.

Hasil analisis kandungan uap air yang diwakili oleh nilai Mixing Ratio dan PW menunjukkan bahwa selama bulan-bulan tersebut kandungan uap air cukup besar. Hasil analisis indeks stabilitas menunjukkan selama bulan pengamatan kondisi atmosfer relatif tidak stabil pada kondisi quite unstable, dengan kategori lemah (weak). Meskipun demikian presipitasi yang dihasilkan dipengaruhi oleh labilitas atmosfer yang diindikasikan oleh

\section{DAFTAR PUSTAKA}

Djuric, D., 1994: Weather Analysis, Prentice-Hall Inc., 304 pp.

Glickman, Todd S., 2000, Glossary of Meteorology, American Meteorologi-cal Society, Cambridge, Massachus-setts.

Irribane and Godson, 1981, Athmospheric Thermodynamics, Volume 6, 2nd edition, D. Reidel, U.S.A.

Rogers, R. R., 1979. A Short Course in Cloud Physics, 2nd Edition, Pergamon Press. Salby, Murry L, 1996, Fundamentals of atmospheric physics, Volume 61, Academic Press, San Diego.

The Universal RAwinsonde OBservation program (RAOB), http://www.raob.com

UPT Hujan Buatan, Laporan Hasil Kegiatan Penerapan Teknologi Modifikasi Cuaca untuk Menambah Cadangan air di PLTA Waduk Kotapanjang dan danau Singkarak tanggal 22 Juni sd. 11 Juli 2010, Jakarta, 2010.

UPT Hujan Buatan, 2010, Laporan Hasil Kegiatan Penerapan Teknologi Modifikasi Cuaca untuk Menambah Cadangan air di PLTA Waduk Kotapanjang dan danau Singkarak tanggal 8 sd. 21 November 2010, Jakarta.

Wallace, John. M and Peter V. Hobbs. 1977. Atmospheric Science: An Introductory Survey. Academic Press, Inc. New York. 
